Jan., Feb., March, 1951

\title{
Pileated Woodpecker
}

\author{
BY B. J. MOREHOUSE, Ridgefield, Conn.
}

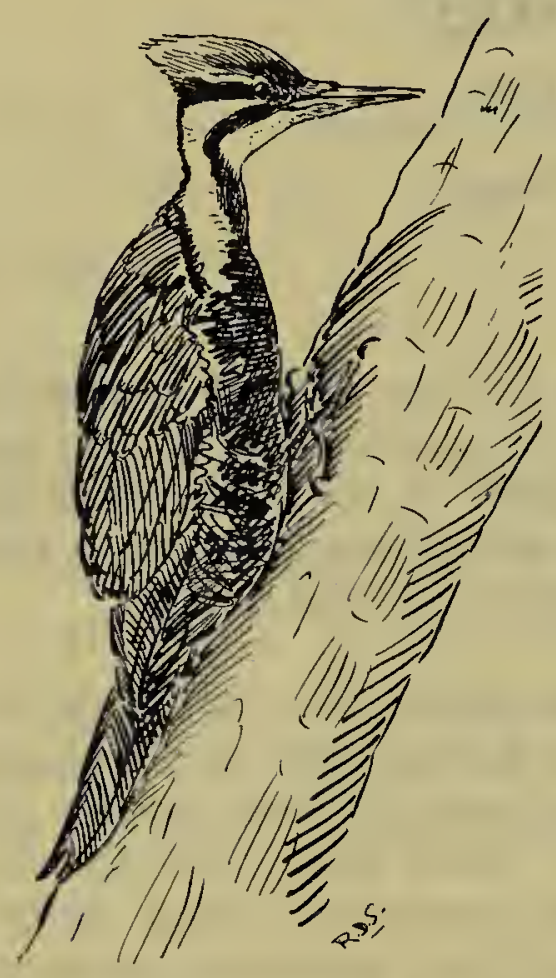

In the last issue of the Blue Jay on page 11 there occurs a note about the occurence of the Pileated Woodpecker and its comparative rarity in general.

The above note is of interest to me because of the following experience of mine of recent date. About a year ago a neighbor called my attention to this fact. Knowing of my interest in the happenings of natural history around us this friend realized the unusual was taking place, namely that a large blackish bird with a red crest, etc, , had the habit of appearing in the morning once or twice a week and in woodpecker fashion creeping up the large trees and drilling into the wood huge deep holes.

When I was acquainted with the fact I came to the conclusion that a Northern Pileated Woodpecker was visiting our region. Throughout the winter I made great efforts to personall $y$ see the bird and possibly secure pictures of it. Unfortunately I was disappointed and never made contact. I am in the hopes the bird or birds will visit this area again this winter. The bird had a habit of flying away from my neighbors's home in a certain direction, and last spring I had work to do in the woods about 1000 feet from my neighbors and in the direction which the bird took in flying away. There, numerous fallen trees dead and decayed, were literally full of large deep bored holes, undoubtedly made by this pileated bird. The holes were too large to have been made by our common Bowny and Hairy Woodpeckers, so I feel confident that the Pileated Woodnecker was a visitant to Ridgefield, Conn.

My Conn. Geol. \& Natural History bulletin lists the Pileated Woodpecker as very rare in occurence, having been noted only about a dozen times in the last 75 years and two breeding records in the last 60 years.

While commenting on the above facts I would like to state that in 1945 when on a visit to Mellvile, Yorkton and Bredenbury for observations of the solar eclipse, I became acquainted with Mrs. I. M. Priestly and her intense interest and fascination with the doings of Nature. While concerned with the doings of the solar eclipse expedition, I was able to observe both plant and bird happenings. It was another pl easant memory I am able to retain of that trip that I found my first and only natural Yellow Lady slipper near Bredenbury. I have never found it in my own native state here, although it isn't considered to be very rare either. When I told Mrs. Priestly of my find she seemed as pleased as I was. Hence my continuing interest and hopes for the future success of her BL UE JAY as one of those good things in this world of ours we all should strive to perpetuate.

\section{Rare at High Ilill, Sask.}

Mr. Anton Waycheshen reports that Pileated woodpeckers are quite rare in his district, al though several are seen each year. He feels certain that the se birds nest near High Hill, but a,s yet has been unable to locate one. $\mathrm{He}$ believes that such conspicuous birds fall easy prey to thoughtless gunmen and attributes their scarcity to this fact. 